\title{
Review of Literature of Science Process Skill in Curriculum 2013 at Elementary School
}

\author{
$1^{\text {st }}$ Pipit Fitri Amarta \\ Department of Primary Education, \\ Faculty of Teacher Training and \\ Education Universitas Sebelas \\ Maret Surakarta, Indonesia, \\ 57126 \\ silviapuspitaD@gmail.com
}

$2^{\text {nd }}$ Sarwanto

Department of Pysics Education, Faculty of Teacher Training and Education, Universitas Sebelas Maret, Surakarta, Indonesia, 57126

Sar1to@yahoo.com $3^{\text {rd }}$ Peduk Rintayati

Department of Primary Education, Faculty of Teacher Training and Education, Universitas Sebelas Maret, Surakarta, Indonesia, 57126

pedukrintayati@ymail.com

\begin{abstract}
This article describes science process skills in elementary schools, especially curriculum 2013 in Indonesia. The method of this research is a literature review, which collects and analyzes the literature in the form previous research by using descriptive analysis based on variable regression. The results of this study show the scientific approach of curriculum 2013 in Indonesia according to Science process skill. The results of this study indicate a scientific learning that implements the implementation learning on scientific principles to build students' thinking skills accordingly with the curriculum 2013 and skills in the science process skills essential for training learners in conducting scientific activities. These skills are 1) observing; 2) interpreting observations; 3) predict; 4) using tools and materials; 5) apply the concept; 6) plan research; 7) communicate.
\end{abstract}

Keywords: curriculum 2013, elementary school, science process skills.

\section{INTRODUCTION}

Education is anticipatory, which is to prepare young generation to be able to use the future successfully. The future generation is "millenial party", "iGeneration", "Net Generation", or "children of cyberspace" (Berry \& the Teacher Solutions 2030 Team, 2011) who "not only thinks different things but also different ways of thinking". In this case, Wagner (2008) suggests seven skills to survive in the 21 st century: (1) critical thinking and problem solving, (2) collaboration across networks and leading by influence, (3) agility and adaptability, (4) initiative and entrepreneurialism, (5) effective oral and written communication, (6) accessing and analyzing information, and (7) curiosity and imagination. To prepare future generations, education should be able to give the learners with critical thinking skills, skills to filtering and analyzing the information to solve the problems, cooperating in various situation, quick to adapt, and have an entrepreneurial spirit to be able to find and make innovative and creative ideas. Some of these skills are integrated into curriculum 2013.
Permendikbud No. 65 Year 2013 on the Standard Process of Primary and Secondary Education to allow the process of learning guided by scientific / scientific approach principles. The scientific approach is one of the characteristics that is considered to be the strength of Curriculum 2013 which is currently rife disseminated implementation in various regions in Indonesia. This scientific approach is believed to be a bridge and development of attitudes, skills, and knowledge about learning. The scientific approach refers to the investigation of phenomena or symptoms, the acquisition of new knowledge and the integration and also updating the previous knowledge.

Yamtinah (2015) describes the scientific approach referred to the 2013's curriculum is scientific learning approach, that is the learning which consists of observing activities (to identify things they want to know), making questions (and formulating hypotheses), trying / collecting data (information) with various techniques, linking / analyzing / processing data (information) and for making conclusions and communicating the results which consist of conclusions to get a knowledge, skills, and attitudes. Besides, SPS is useful for students to get to know the world around them scientifically so that in the future, they can build the concept of science (Yamtinah, 2017). Therefore, the knowledge and application of the skills need to be known by elementary school teachers. Elementary schools are needed because at this stage, it is the right time to make students into a person which has KPS.

\section{METHOD}

This research was a qualitative research with in-depth This study uses literature review method, which collects and analyzes the literature in the form previous research by using descriptive analysis based on variable regression. This research is conducted to know how far the application of science process skill in applying 2013's curriculum in Indonesia. The literature used as a researcher to conduct the literature 
study in several international journals, national journals, and books that relevant to the study.

SPS is a student's ability to apply the scientific methods in understanding, developing, and discovering science (Dahar: 1996). Science process skills are also not only applied in the learning process in the classroom but also a provision in solving problems in everyday life. Based on standard analysis of science subject especially on scientific competence, elementary students need to know the skill of science process (Rahayu, 2017).

TABLE 1. The Result of Previous Research from International Journal

\begin{tabular}{|c|c|}
\hline Researchers & Research Result \\
\hline $\begin{array}{l}\text { Aydoğdu, Tatar, Yildız- } \\
\text { Feyzioğlu \& Buldur, } \\
2012 ;\end{array}$ & $\begin{array}{l}\text { Scientific process skills } \\
\text { are one of the most } \\
\text { commonly used thinking } \\
\text { skills. }\end{array}$ \\
\hline Rillero, 1998 & $\begin{array}{l}\text { Individuals who can not } \\
\text { use SPS will experience } \\
\text { difficulty in everyday life } \\
\text { because these skills are } \\
\text { not only used during } \\
\text { education but also used } \\
\text { in everyday life. }\end{array}$ \\
\hline Kazeni, 2005 & $\begin{array}{l}\text { The development of } \\
\text { science skills allows } \\
\text { students to get the skills } \\
\text { to solve everyday } \\
\text { problems. }\end{array}$ \\
\hline
\end{tabular}

The results mentioned above show that SPS is a commonly used thinking skill. This skill is used not only in the school, but on everyday life. The skills in this SPS are in accordance with the curriculum applied in Indonesia which has been known to use a scientific approach.

TABLE 2. The Result of Previous Research from National Journal

\begin{tabular}{ll}
\hline Researchers & Research Result \\
\hline Anam, 2014 & This research conducted a \\
& research on thirty (30) \\
& representative students \\
& from 30 Madrasah School \\
& in Sumedang District on \\
& competence of madrasah \\
& science activities. The \\
& results showed that four \\
& (4) types of students \\
& process skill were \\
& observing, planning \\
& experiments, classifying, \\
& and making list in a less \\
& proficient category, and \\
& not skilled in concluding \\
& skills. \\
\hline Sukarno, $\quad$ Permanasari & The skill of science \\
\hline
\end{tabular}

\begin{tabular}{ll}
\hline dan Hamidah, 2013 & $\begin{array}{l}\text { process of the junior high } \\
\text { school student in Jambi in } \\
\text { making a conclusion, } \\
\text { observation, prediction, } \\
\text { measure, and classify are } \\
\text { still low. }\end{array}$ \\
\hline Ai Hayati Rahayu, 2017 & The skill of science \\
& $\begin{array}{l}\text { process of an elementary } \\
\text { school student in }\end{array}$ \\
& Sumedang Regency for \\
& every aspect of KPS is \\
& still low, with $49,7 \%$
\end{tabular}

Some of the studies from the previous research that have been described above can be concluded that the science process skill in Indonesia still shows relatively low results. Observing skills, planning experiments, classifying and creating tables still show low relative results. This is also supported by PISA data in 2006 indicating that $61.6 \%$ of Indonesian students have limited science knowledge. In relation to process skills, the ability of Indonesian students to conduct simple research is only $27.5 \%$. Based on the 2007 TIMSS (Trends International Mathematics Science) survey, which measures the scientific inquiry ability of students, it is found that Indonesian students' science achievement is ranked 36 out of 49 countries. Although based on the average value, an increase in the value of PISA Indonesia in the three competences tested. The largest increase seen in science competence, from 382 points in 2012 to 403 points in 2015. In the mathematical competence increased from 375 points in 2012 to 386 points in 2015. Reading competencies have not shown significant increase, from 396 in 2012 to 397 points in 2015. The increase elevates Indonesia's position to 6th place upward compared to the second-ranked position from below in 2012 .

TABLE 3. Science Process Skills Category by Rezba (1995)

\begin{tabular}{ll}
\hline Basic Skills & Advanced Skills \\
\hline Observasi & Variable Control \\
Measure & Data Interpretation \\
Inferensi & Hypothesis Formulation \\
Prediksi & Defining Variables \\
& Operationally \\
Classifyng & Designing Experiments \\
Communication & Doing Experiment \\
\hline
\end{tabular}

The science process skills that Rezba (1995) differentiates into two parts: basic skills and advanced skills. These basic skills are more emphasized in the 2013 curriculum in primary schools in Indonesia. However, in this 2013 curriculum many experiments to further deepen the material, so that students have direct experience in learning. This learning experience makes the students more make students think critically, so that the resulting learning is student centered learning. 
In Padilla (1990) scientific process skill is defined as a set of abilities which can be moved with many disciplines of science and reflecting the behavior of scientists. SAPA classifies the process skills into two, which are basic and integrated types. Basic (simple) process skills provide a basic learning of integrated skills (more complex). These basic science process skills include observing, inferring, measuring, communicating, grouping, and predicting skills. While integrated process skills include controlling variables, defining operationally, formulating hypotheses, interpreting data, experimenting, and formulating models (Padilla, 1990).

Jingks (1997) provides a list of 13 scientific processes recommended by the American Association for the Advancement of Science (AAAS). The first 8 processes are called "basic process" and suitable for children in the main class. The last five are called "integrated process" and more suitable for children in 4 th and above grades.

1. Observation can be defined as collecting information through the use of one, or a combination of the five basic senses; vision, hearing, touch, taste, and smell.

2. Measurement is a specific observation by comparing several attributes of a system with reference standard.

3. Classification is the process of grouping objects based on observable traits. Objects that have certain characteristics can be said to be included in the same series.

4. Quantification refers to the process of using numbers to express observations than only rely on qualitative descriptions.

5. Inferring is an inventive process where a cause assumption is generated to explain the observed event.

6. Predict is a process that related to predicting events based on an information.

7. Relationships, relationship process skills related to variables interaction.

8. Communicating, this process actually refers to a group of skills that is systematic data reporting.

9. Interpreting data, this process refers to the intrinsic ability to recognize patterns and associations in a data.

10. Controlling variables, the process is the attempt to achieve a state or condition where the impact of one variable is clearly exposed.

11. Operational definition, the main function of the operational definition is to set a conclusion in an attempt to obtain a higher level of objectivity.

12. Hypothesis, is an intrinsic and creative mental process than a behavior that is more straight forward and clear.

13. Experiment, this process is a systematic approach to solve a problem.
For science learning in elementary schools, Herlen (2013) suggests that only a few types of process skills required. This basic level of process skills is called basic science process skills. The five types of skills that Herlen suggests are observing (collecting data, measuring), planning (raising questioning, predicting, devising enquiries), hypothesizing (suggesting, explanation), interpreting (considering evidence, evaluating), and communicating (presenting report, using secondary sources).

While Rezba (1995) classifies the basic science process skills into 6 types of skills. This skill is what people do when they work on 'science', that is: observing, classifying, measuring, summing up, predicting, and communicating. Students use the senses to observing the objects and events and see the patterns from observations. They classify new concepts based on the similarities and differences. Students both verbally and writing communicate what they know and can do. They measure to quantify objects and events. Students conclude the explanation and want to change the conclusion if there is new information. Students also predict the possibilities that will happen before they actually do the observation.

In curriculum 2013, the mastery of science process skills is explained on the basic science skills of the 4th competency (skill competency). Basic competencies for IV class include: observing, creating written reports, creating tables or graphs, conducting and presenting experimental results, creating works/models.

\section{CONCLUSION}

Scientific process skills become one of the components needed in the 2013 curriculum in Indonesia, especially elementary schools. Science process skill can used in everyday life, not only in school. Scientific learning that implements the implementation learning on scientific principles to build students' thinking skills accordingly with the curriculum 2013 and skills in the science process skills essential for training learners in conducting scientific activities. These skills are 1) observing; 2) interpreting observations; 3) predict; 4) using tools and materials; 5) apply the concept; 6) plan research; 7) communicate.

\section{ACKNOWLEDGMENTS}

The authors would like to give a sincere gratitude to the two mentoring lecturers, Sarwanto, and Peduk for their guidance and direction to carry out this research and article writing.

\section{REFERENCES}

[1] Ai Hayati Rahayu dan Poppy Anggraeni. 2017. Analisis Keterampilan Proses Sains Siswa Sekolah Dasar di 
Kabupaten Sumedang. Jurnal Pesona Dasar. Vol.05 No.2 Oktober 2017. Hal 22-23.

[2] American Association for the Advancement of Science (AAAS). (1967). Science-A Process Approach. Washington, D.C: American Association for the Advancement of Science.

[3] Anam, R. S., (2014). Analisis Keterampilan Proses sains Siswa Madrasah Ibtidaiyah di Kabupaten Sumedang. Prosiding Konfrensi Pendidikan Dasar SPs UPI 2014: Pendidikan Berkualitas Dalam Membangun Generasi Emas 2045. Halaman 274-282.

[4] Aydoğdu, B., Tatar, N., Yıldız-Feyzioğlu, E., \& Buldur, S. (2012). İlköğretim öğrencilerine yönelik bilimsel süreç becerileri ölçeğinin geliştirilmesi [Developing a science process skills scale for elementary students]. Kuramsal Eğitimbilim Dergisi, 5(3), 292-311.

[5] Berry, B. \& the Teacher Solutions 2030 Team. (2011). Teaching 2030: What we must do for our students and our publis schools, now and the future. New York - London: Teachers College Press Columbia University.

[6] Dahar, R. W. 1996. Teori-teori Belajar. Erlangga. Jakarta.

[7] Harlen, W. (2013). Assessment \& Inquiry-Based Science Education: Issues in Policy and Practice. Trieste: The Global Network of Science Academies Science Education Programme.

[8] Jinks, J., (1997). The Science Processes. [Online]. Http://My.Ilstu.Edu.
[9] Kazeni, M.M.M. (2005). Development and validation of a test integrated science process skills for the further education and training learners. (Unpublished Master Thesis), University of Pretoria, South Africa.

[10] Padilla, M. J., (1990). The Science Process Skills. Research Matters - To The Science Teacher No. 9004. [Online]. https://www.narst.org/publications/research/skill.cfm.

[11] Rezba, Richard J., et.al. Learning and Assessing Science Process Skill. (Iowa: Kendall/Hunt Publishing Co, 1995).

[12] P. Rillero. 1998. Process skills and content knowledge Science Activities, 35 (3) (1998), pp. 3-5

[13] Sukarno, Permanasari, A., dan Hamidah, I., (2013). The Profile of Science Process Skills (SPS) Students at Secondary High School (Case Study in Jambi). International Journal of Scientific Engineering and Research (IJSER). ISSN [Online] 2347-3878 Vol I Isue 1 September 2013. www.ijser.in.

[14] Wagner, T. (2008). The global achievement gap: Why even our best schools don't teach the new survival skills our children need, and what we can do about it. New York: Basic Books - Perseus Books Group.

[15] Yamtinah, Sri. (2017). Content Validity and Scoring of Two Tier as Measuring Instrument of Science Process Skills for Knowledge Aspects in Chemistry Learning. Prosiding ICTTE FKIP UNS 2015. Vol 1, Nomor 1, Januari 2016 